\title{
PENERAPAN REALISTIC MATHEMATIC EDUCATION DALAM MENINGKATKAN HASIL BELAJAR SISWA KELAS V PADA MATERI VOLUME BANGUN RUANG DI SEKOLAH DASAR
}

\author{
Yeni Dwi Kurino \\ Yenidwi_kurino@yahoo.com \\ Universitas Majalengka
}

\begin{abstract}
ABSTRAK
Penelitian ini dilatarbelakangi oleh rendahnya hasil belajar siswa kelas V SD. Berdasarkan hasil observasi di lapangan bahwa banyak siswa yang kesulitan dalam menyelesaikan soal volume bangun ruang yang diberikan oleh peneliti. Tujuan dari penelitian ini yaitu untuk meningkatakan hasil belajar siswa setelah menggunakan model Realistic Mathematic Education. Peneliti menggunakan Realistic Mathematic Education dalam meningkatkan hasil belajar siswa. Melalui model ini siswa mampu diarahkan untuk senantiasa berpikir kritis, kreatif, dan metakognitif. Metode penelitian yang digunakan adalah metode penelitian tindakan kelas (PTK) dengan menggunakan model kemmis taggart. Penelitian ini dilaksanakan dalam tiga siklus, yang setiap siklusnnya terdiri dari tiga tindakan. subjek penelitian adalah siswa kelas V sebanyak 19 orang. Pelaksanaan penelitian terdiri dari tiga siklus dan setiap siklus terdiri dari dua tindakan. Teknik pengumpulan data dilakukan dengan menggunakan lembar observasi, catatan lapangan, lembar wawancara, lembar evaluasi dan kamera. Dari Hasil belajar yang diperoleh setiap siklus mengalami peningkatan. Ratarata hasil belajar siklus I mencapai 52,25, rata - rata hasil belajar Siklus II 74,34, dan rata - rata hasil belajar siklus III mencapai 92,34.. Dengan demikian peneliti menyimpulkan bahwa model pembelajaran Realistic Mathematic Education dapat meningkatkan Hasil Belajar siswa kelas V Sekolah Dasar.
\end{abstract}

Kata Kunci: Realistic Mathematic Education, Hasil Belajar 


\section{PENDAHULUAN}

Perubahan kurikulum sekolah dilakukan pemerintah sebagai upaya meningkatkan mutu pendidikan dan Sumber Daya Manusia (SDM) bangsanya. Sebagaimana tersurat di dalam kurikulum 2006 (Depdiknas, 2006: 3), yaitu:

...peningkatan mutu pendidikan

diarahkan untuk meningkatkan

kualitas manusia Indonesia

seutuhnya melalui olahhati,

olahpikir, olahrasa dan olahraga

agar memiliki daya saing dalam

menghadapi tantangan global.

Peningkatan relevansi pendidikan

dimaksudkan untuk menghasilkan

lulusan yang sesuai dengan tuntutan

kebutuhan berbasis potensi sumber

daya alam Indonesia...

Salah satu kelompok mata pelajaran yang terdapat dalam kurikulum 2006 (Depdiknas, 2006:4), adalah Ilmu Pengetahuan dan Teknologi (IPTEK). Kelompok mata pelajaran IPTEK merupakan kelompok mata pelajaran yang paling menitik beratkan pada keterampilan tingkat tinggi tersebut. Hal ini sesuai dengan cakupan kelompok mata pelajaran IPTEK dalam kurikulum 2006 (Depdiknas, 2006:5), yaitu : Kelompok mata pelajaran ilmu pengetahuan dan teknologi pada SD/MI/SDLB dimaksudkan untuk mengenal, menyikapi dan mengapresiasi ilmu pengetahuan dan teknologi, serta menanamkan kebiasaan berpikir dan berperilaku ilmiah yang kritis, kreatif dan mandiri.

Berdasarkan uraian mengenai kelompok mata pelajaran di atas, maka jelaslah bahwa mata pelajaran matematika di Sekolah Dasar (SD) termasuk ke dalam kelompok mata pelajaran IPTEK. Adapun latar belakang perlunya mata pelajaran matematika diberikan kepada semua peserta didik mulai dari SD, tercantum dalam kurikulum 2006 (Depdiknas,
2006:109) “...untuk membekali peserta didik dengan kemampuan berpikir logis, analitis, sistematis, kritis dan kreatif serta kemampuan bekerjasama" Sedangkan aspek-aspek mata pelajaran matematika pada satuan pendidikan SD/MI dalam kurikulum 2006 (Depdiknas, 2006:110), adalah "bilangan, geometri dan pengukuran, serta pengolahan data".

Materi bangun ruang merupakan bagian dari aspek geometri yang menekankan pada kemampuan siswa untuk mengidentifikasi sifat dan unsur serta menentukan volume dalam pemecahan masalah. Seperti halnya materi bangun ruang yang dipelajari di kelas V SD semester dua yang dimulai dari sifat-sifat bangun ruang, menentukan volume bangun ruang sederhana (kubus dan balok) sampai pada menentukan volume limas dan kerucut.

Mengingat tuntutan terhadap penguasaan materi bangun ruang di kelas V SD semester dua memerlukan penalaran yang cukup tinggi dan agar tujuan pembelajaran matematika dapat tercapai optimal, maka dalam menyajikan materi bangun ruang, guru hendaknya memperhatikan karakteristik siswa. Hal ini dapat dilaksanakan guru dengan memenuhi tuntutan karakteristik siswa, seperti memberikan kesempatan kepada siswa untuk aktif dalam pembelajaran. Hal ini perlu dilaksanakan guru karena siswa telah memiliki banyak pengetahuan melalui pengalaman sehari-harinya.

Pemahaman serta penerapan teori-teori belajar dan teori-teori perkembangan siswa penting dan harus dikuasai seorang guru, temasuk oleh guru SD. Guru SD harus dapat memilah dan memilih teori-teori belajar yang cocok dengan perkembangan siswanya. Jangan sampai menganut dan melaksanakan pembelajaran yang bersumber pada teori atau lebih tepatnya asumsi tabula rasa John Locke (Lie, 2005:2) yaitu: Pikiran seorang anak seperti 
kertas kosong yang putih bersih dan siap menunggu coretan-coretan gurunya. Dengan kata lain, otak seorang anak ibarat botol kosong yang siap diisi dengan segala ilmu pengetahuan dan kebijaksanaan sang maha guru.

Dengan demikian, jelaslah bahwa asumsi tabula rasa John Locke dalam pembelajaran dilakukan guru dengan memberikan pengetahuan kepada siswa secara pasif, guru hanya seolah menuangkan apa yang diketahuinya kepada siswa, ibarat mengisi air ke dalam botol kosong yang siap menerimanya dan disebut pembelajaran yang berpusat kepada guru.

Kenyataan di lapangan sebagaimana dikemukakan di atas, juga ditemui peneliti dalam pembelajaran matematika. Peneliti memperoleh temuantemuan mengenai sikap siswa selama pembelajaran matematika, siswa mengalami kejenuhan selama pembelajaran matematika karena pembelajaran kurang menarik. Hal ini, mengakibatkan sebagian besar siswa sukar memahami setiap konsep yang diajarkan, tidak terkecuali dalam pembelajaran konsep volume bangun ruang di kelas $\mathrm{V}$ SD. Kejenuhan tersebut diakibatkan guru dalam menyajikan materi kurang memberikan kesempatan kepada siswa untuk lebih aktif dalam pembelajaran, karena lebih menekankan kepada simbolsimbol langsung tanpa memberikan kesempatan seluas-luasnya kepada siswa untuk aktif memanipulasi model-model bangun ruang secara langsung, sehingga hasil belajar mereka dalam materi geometri khususnya menentukan volume bangun ruang menjadi rendah. Temuan peneliti di lapangan yang paling mendasar adalah: konsep prasyarat yang kurang kuat dimiliki siswa, sehingga siswa mengalami kesulitan dalam menunjukkan dan menyebutkan unsur-unsur atau sifat-sifat bangun ruang (sisi, sudut, rusuk) dan menyebabkan siswa sulit mempelajari volume bangun ruang. Dalam hal ini, penguasaan konsep siswa kelas V SD tentang volume bangun ruang tidak utuh, pada umumnya siswa hanya mampu menghafal dan menerapkan rumus volume bangun ruang yang penyajian soalnya dalam bentuk gambar, apabila soal disajikan dalam bentuk soal seperti soal cerita siswa mengalami kesulitan. Hal ini membuktikan bahwa konsep prasyarat mengenai sifat-sifat bangun ruang kurang dikuasai siswa.

Berdasarkan temuan di lapangan tersebut, peneliti berinisiatif untuk melakukan Penelitian Tindakan Kelas (PTK) yang berjudul " Penerapan Realistic Mathematic Education dapat meningkatkan hasil belajar siswa Kelas V pada materi Volume Bangun Ruang di Sekolah Dasar".

\section{TINJAUAN PUSTAKA}

\section{A. Pendekatan Realistic Mathematic Education}

Langkah awal seorang guru sebelum mengajar adalah menetapkan tujuan yang ingin dicapai dalam proses pembelajaran. Untuk mencapai tujuan yang hendak dicapai itu harus dipilih pendekatan yang tepat sehingga diperoleh hasil yang optimal, berhasil guna dan tepat guna. Pendekatan pembelajaran matematika adalah cara yang ditempuh guru dalam pelaksanaan pembelajaran matematika agar konsep yang disajikan dapat dipahami oleh siswa.

Seorang guru dapat memilih pendekatan pembelajaran yang sesuai untuk membelajarkan siswanya. Hal ini tergantung pada kemampuan guru dan siswa serta materi yang akan diajarkan. Demikian pula dengan pendekatanpendekatan matematika lainnya yang dipakai oleh para guru dalam meningkatkan pemahaman dan hasil belajar dalam pembelajaran matematika. Masing - masing pendekatan mempunyai kekhasan dan karakteristrik tersendiri. Salah satu pendekatan pembelajaran matematika adalah pendekatan Realistic 
Mathematic Education. Pendekatan Realistic Mathematic Education diketahui sebagai pendekatan yang telah berhasil di Nederlands. Sampai sekarang pendekatan ini telah mengalami perkembangan di seluruh dunia, termasuk Indonesia. Menurut hasil penelitian siswa di dalam pendekatan Realistic Mathematic Education mempunyai skor yang lebih tinggi dibandingkan dengan siswa yang memperoleh pembelajaran dengan pendekatan tradisional dalam hal keterampilan berhitung lebih khusus lagi dalam aplikasi ( MKPBM, 2001: 125 \}.

Dalam praktek pembelajaran matematika di kelas, Realistic Mathematic Education sangat memperhatikan aspek aspek informal kemudian mencari jembatan untuk mengantar pemahaman siswa kepada matematika formal. Menurut Treffers dan Goffree (MKPBM, 2001 : 129) dalam proses permatematikaan dibedakan 2 komponen proses matematisasi yaitu horizontal mathemazation dan vertikal mathemazation. Berdasarkan teori itu, mula - mula seseorang dapat mengidentifikasi bagian dari matematisasi yang bertujuan untuk mentransfer suatu masalah ke dalam masalah yang dinyatakan secara matematika.

Menurut Freudenthal ( MKPBM , 2001 : 126) pendidikan matematika harus mengarahkan siswa untuk menemukan kembali matematika dengan cara mereka sendiri. Banyak soal yang dapat diangkat dari berbagai situasi ( konteks ) yang dirasakan bermakna sebagai sumber belajar. Konsep matematika yang muncul dari proses matematisasi, yaitu penyelesaian yang berkaitan dengan konteks (Conteks-Link Sosution) siswa secara perlahan mengembangkan alat dan pemahaman matematika ketingkat yang lebih formal. Cara - cara penyelesaian yang muncul dari aktivitas matematika, siswa dapat terdorong untuk terjadi berinteraksi dengan siswa lainnya di kelas sehingga mengarah pada level berpikir matematika yang lebih tinggi.

Menurut Kolb ( Tarmudi, 2001 : 1 ) belajar sebaiknya ditempuh sebagai proses bukan sebagai hasil. Karenanya proses matematisasi menjadi sangat penting dalam kerangka pembelajaran dengan pendekatan Realistic Mathematic Education. Pada pendekatan Realistic Mathematic Education proses belajar merupakan kegiatan yang penting dalam pembelajaran matematika. Proses pembelajaran matematika akan melekat dan bermakna bagi siswa apabila proses yang terjadi selama pembelajaran siswa mengkonstruk ide-ide yang dimilikinya dalam matematika.

1. Ciri - ciri Pendekatan Realistic Mathematic Education

Menurut Gravemeijer (Tarmudi, 2003 : 1) pada pembelajaran realistik terdapat 5 prinsip utama atau ciri - cirri kegiatan Realistic Mathematic Education yaitu :

a) didominasi oleh masalah - masalah dalam konteks, maksudnya adalah untuk melayani 2 hal yaitu sebagai sumber dan sebagai terapan konsep matematika ;

b) perhatian diberikan kepada pengembangan model-model, situasi, skema dan simbol - simbol ;

c) sumbangan dari siswa, dimana siswa dapat membuat pembelajaran menjadi konstruktif dan produktif, artinya siswa memproduksi sendiri dan mengkonstruksi sendiri (yang mungkin berupa algoritma dan aturan), sehingga dapat membimbing siswa dari level matematika informal menuju matematika formal ;

d) interaktif sebagai karakteristik dari proses pembelajaran matematika ;

e) membuat jalinan antar topik atau antar pokok bahasan.

2. Pembelajaran Realistic Mathematic Education

Pemikiran yang Melandasi

Pembelajaran Realistic Mathematic 
Education dalam pengembangan Realistic Mathematic Education di dasarkan pada pandangan Freudental terhadap Realistic Mathematic Education. Freudental ( Armanto : 2002 ) berpandangan sebagai berikut :

a.matematika harus dikaitkan dengan hal yang nyata bagi siswa.

b. matematika harus dipandang sebagai aktivitas manusia.

Pertama, untuk memulai dari fenomena atau kejadian yang riil bagi siswa menurut freudental didactical phenomology pada saat belajar siswa memulai dari masalah yang bersifat kontekstual yang pada akhirnya dapat digunakan untuk memecahkan konsep matematika. Kedua, dengan menggunakan prinsip guided reinvention melalui progressive mathematization, siswa digiring secara didaktik dan efisien dari suatu level berpikir kelevel berikutnya melalui matematisasi. Kedua prinsip ini dan prinsip self developed models ( Gravemeijer, 1998 ) dioperasionalisasikan ke dalam lima karakteristik dasar dari realistik Mathematics Education.

Menurut De Lange (Suharta: 2002) bahwa proses pengembangan konsep RME dan berbagai gagasan matematika bermula dari dunia nyata dan pada akhirnya perlu direflesikan hasil - hasil yang diperoleh dalam matematika tersebut direfleksikan ke dalam bentuk alam yang nyata. Artinya apa yang dilakukan dalam proses matematika adalah menerapkan sesuatu dari bentuk dunia nyata dibawa kedalam model matematika. Dan pada akhirnya dikembalikan lagi kebentuk alamnya.

Sejalan dengan itu menurut Soejadi ( Suharta : 2002 ) Realistic Matematic's Education ( RME) memiliki filsafat dasar yaitu bahwa " Matematika adalah aktivitas manusia, " dan tidak lagi dipandang " Siap Pakai " Filsafat ini mengakibatkan perubahan yang amat mendasar tentang proses pembelajaran metematika tidak lagi hanya pemberian informasi dalam pembelajaran matematika. Tetapi harus mengubah menjadi aktivitas manusia untuk memperoleh pengetahuan matematika. Menurut Soedjadi ( Armanto 2002 ) Realistic Mathematic Education memiliki prinsip :
1) Reinvention dan progressive matemetization

2) Ditactical phenomenologi

3) Self-developed model

Implementasi pendidkan Realistic Mathematic Education di Indonesia harus dimulai dengan mengadaptasi pembelajaran Realistic Mathematic Education sesuai dengan karakteristik dan budaya bangsa Indonesia. Pengimplementasian pembelajaran Realistic Mathematic Education di kelas harus didukung oleh sebuah perangkat yang dalam hal ini adalah buku pelajaran yang sesuai dengan kondisi bangsa Indonesia. Menurut Suharta ( Armanto : 2002 ) bahwa Implementasi PMR di kelas meliputi tiga fase yaitu : Fase Pengenalan, Fase Eksplorasi, dan Fase Meringkas.

Pada fase pengenalan, peneliti memperkenalkan masalah - masalah realistik dalam pembelajaran matematika kepada seluruh siswa serta membantu siswa memberi pemahaman masalah. Pada fase ini meninjau ulang semua konsep konsep yang berlaku sebelumnya dan mengaitkan masalah yang dikaji saat itu ke pengalaman siswa sebelumnya yang terjadi dalam kehiduoan sehari - hari.

Pada Fase eksplorasi, siswa dianjurkan bekerja secara Individual, berpasangan atau dalam kelompok kecil. Pada saat siswa sedang bekerja, mereka mencoba membuat model situasi masalah, berbagai pengalaman atau ide, mendiskusikan pola yang dibentuk saat itu, serta berupaya membuat dugaan. Selanjutnya dikembangkan strategi-strategi pemecahan masalah yang mungkin dilakukan berdasarkan pada pengetahuan informal atau formal yang dimiliki siswa. Disini guru berupaya meyakinkan siswa dengan cara memberi pengertian sambil berjalan mengelilingi siswa, melakukan 
pemeriksaan terhadap pekerjaan siswa dan memberi motivasi kepada siswa untuk giat belajar. Dalam hal ini peran guru adalah memberikan bantuan seperlunya kepada siswa yang memerlukan bantuan. Bagi siswa yang berkemampuan tinggi dapat diberikan pekerjaan yang lebih menantang yang berkaitan dengan masalah.

Pada fase meringkas, guru dapat mengawali pekerjaan lanjutan setelah siswa menunjukkan kemajuan dalam pemecahan masalah. Sebelumya mendiskusikan pemecahan - pemecahan dengan berbagai strategi yang mereka lakukan. Dalam hal ini guru membantu siswa meningkatkan kinerja matematika secara lebih efisien dan efektif. Peranan siswa dalam fase ini sangant penting seperti : mengajukan dugaan, mengajukan pertanyaan kepada yang lain, bernegosasi, memberi alternatif-alternatif pemecahan masalah, memberikan alasan, memperbaiki strategi dari dugaan mereka, dan membuat keterkaitan. Sebagai hasil dari diskusi, siswa diharapkan menemukan konsepkonsep awal / utama atau pengetahuan matematika formal sesuai dengan tujuan materi. Dalam fase ini guru juga dapat membuat keputusan pengajaran yang memungkinkan semua siswa dapat mengaplikasikan konsep.

\section{Pembelajaran Volume Bangun Ruang}

Volume bangun ruang merupakan bagian dari ruang lingkup geometri di kelas V SD semester II. Penjabaran bahan pengajaran geometri dalam kurikulum matematika SD tahun 2006 (Depdiknas, 2006:110), adalah sebagai berikut:

6.1 Mengidentifikasi sifat-sifat bangun datar

6.2 Mengidentifikasi sifat-sifat bangun ruang

6.3 Menentukan jaring-jaring berbagai bangun ruang sederhana

6.4 Menyelidiki sifat-sifat kesebangunan dan simetri
6.5 Menyelesaikan masalah yang berkaitan dengan bangun datar dan bangun ruang sederhana .

Sebelum membelajarkan materi volume bangun ruang, hendaknya kita memahami definisi bangun ruang itu sendiri, Ruseffendi (2005:78) menyatakan:

Dalam mendiskusikan daerah bidang didefinisikan bahwa daerah bidang itu merupakan gabungan lengkungan tertutup sederhana dengan daerah dalamnya. Begitu pula mengenai benda ruang, daerah ruang adalah gabungan antara permukaan tertutup sederhana dan bagian dalamnya.

Materi bangun ruang di kelas V SD, difokuskan kepada kubus, balok, tabung, prisma, limas dan kerucut. Pembahasan materi tersebut, sesuai dengan yang diutarakan Piaget (Windayana et al. 2006:17) bahwa:

Siswa memiliki kemampuan konservasi/hukum kekekalan secara terurut seperti: kekekalan bilangan, panjang, materi, luas. Sedangkan kekekalan volume dikuasai siswa di masa-masa akhir tahap ini, atau di awal tahap formal (akhir usia $\mathrm{SD} /$ kelas tinggi).

Pada penelitian tindakan kelas ini, peneliti membatasi materi yang akan dijadikan sebagai fokus penelitian yaitu materi mengenai limas segiempat, limas segitiga dan kerucut.

\section{METODE PENELITIAN}

Penelitian yang dilaksanakan merupakan penelitian tindakan kelas (classroom action research) yang mengacu kepada tindakan guru ketika melaksanakan pembelajaran sebagai upaya untuk memperbaiki kegiatan pembelajaran yang telah dilaksanakan. Hal ini sesuai dengan pernyataan Arikunto (2006:61) mengungkapkan bahwa tujuan Penelitian tindakan kelas antara lain sebagai berikut: (1) Meningkatkan mutu isi, masukan, proses, serta hasil pendidikan dan pembelajaran di sekolah, (2) Membantu 
guru dan tenaga kependidikan lainnya mengatasi masalah pembelajaran dan pendidikan di dalam dan luar kelas, (3) Meningkatkan sikap profesional pendidik dan tenaga kependidikan,

Menumbuhkembangkan budaya akademik di lingkungan sekolah sehingga tercipta sikap proaktif di dalam melakukan perbaikan mutu pendidikan dan pembelajaran secara berkelanjutan (sustainable).

\section{Desain Penelitian}

Prosedur penelitian tindakan kelas ini terdiri dari 3 siklus dan masing-masing siklus terdiri dari 2 tindakan. Setiap tindakan yang dilaksanakan merupakan hasil refleksi dari tindakan sebelumnya, dalam rangka mengadakan perubahan ke arah yang baik sesuai dengan faktor yang diteliti dalam perencanaan. Arikunto (2006:20) mengungkapkan bahwa dalam penelitian tindakan kelas ada empat tahapan penting, yaitu (1) menyusun rancangan tindakan (planning), pelaksanaan tindakan (acting), pengamatan (observing), dan refleksi (reflecting).

\section{HASIL DAN PEMBAHASAN Siklus I \\ a. Tindakan 1 \\ 1) Perencanaan}

Dalam perencanan yang disiapkan oleh peneliti yakni membuat RPP serta menyediakan apa yang diperlukan dalam pelaksanaan tindakan 1. Media yang digunakan yaitu bangun ruang. Dimana bangun ruang tersebut akan diperlihatkan dan diberikan kepada siswa saat proses KBM berlangsung dengan menggunakan Realistic Mathematic Education.

\section{2) Pelaksanaan}

Siklus I tindakan 1 dilaksanakan pada hari Senin, tanggal 6 Januari 2017 di kelas V SDN Cijati. Dari jumlah siswa keseluruhan, yaitu sebanyak 19 orang, yang hadir hanya 18 orang (1 orang tidak hadir dikarenakan sakit). Materi pokok dari tindakan 1 ini, adalah sifat-sifat limas segiempat dengan menggunakan Realistic Mathematic Education dibantu alat peraga berupa model-model limas segiempat baik yang berongga, pejal maupun kerangka.

\section{3)Observasi}

Berdasarkan data yang diperoleh dari catatan lapangan, lembar observasi lembar wawancara dan hasil pengerjaan LKS baik kelompok maupun individu, terdapat beberapa temuan. Temuan pertama, aktifitas siswa pada tahap apersepsi kurang baik karena terlihat tegang dan kaku, hal ini terlihat dari ekspresi wajah yang serius dan duduk tegap, sehingga hasil belajar siswa menjadi rendah karena jumlah siswa yang merespon pertanyaan guru hanya tiga orang atau $16,67 \%$.

\section{4). Refleksi}

Berdasarkan temuan-temuan di atas, maka untuk merencanakan tindakan selanjutnya perlu diperhatikan hal-hal yang ada hubungannya dengan penyajian materi, rencana pembelajaran dan pengkondisian siswa.

Penggunaan Realistic Mathematic Education yang terdiri dari 4 tahap dalam rencana pembelajaran dialokasikan selama 70 menit akan tetapi pada pelaksanaannya berlangsung selama 80 menit 10 menit lebih lama dari rencana. Pada tahap eksplorasi, yaitu pemberian dugaan serta pada tahap diskusi dan penjelasan konsep yaitu pemberian ide, guru kurang memberikan dorongan dan memberikan kesempatan kepada siswa. Dengan demikian, apabila terjadi perbedaan pendapat antara siswa, maka tindakan guru adalah memberikan kesempatan kepada siswa untuk mengemukakan idenya, dan selalu bertanya kepada siswa lain apakah setuju atau tidak sehingga berdampak pada minat dan aktivitas siswa. Materi yang disajikan dalam LKS harus memperhatikan segi kebahasaan yang jelas sesuai dengan tingkat perkembangan siswa. Selain itu, pengkondisian siswa dalam diskusi kelompok, harus lebih diperhatikan. 
Siklus II

\section{a. Tindakan 1}

\section{1) Perencanaan}

a) Peneliti berkonsultasi dengan walikelas $\mathrm{V}$ untuk menentukan waktu pelaksanaan yang dapat digunakan.

b) Peneliti berkonsultasi dengan walikelas $\mathrm{V}$ materi pokok yang akan digunakan dalam pembelajaran.

c) Peneliti menyusun rencana pelaksanaan pembelajaran yang akan dilaksanakan pada siklus II tindakan I sebagai acuan dalam kegiatan pembelajaran.

d) Peneliti menyusun alat pengumpul data, lembar observasi kegiatan guru dan lembar obervasi kegiatan siswa. Dalam pelaksanaan ini peneliti merencanakan pembelajaran matematika.

e) Menyiapkan media bangun ruang.

f) Menyiapkan kamera untuk dokumentasi selama proses pembelajaran.

g) Mempersiapkan soal tindakan I yang akan dilaksanakan pada untuk mengecek seberapa jauh pemahaman siswa tentang materi yang telah diajarkan.

\section{2) Observasi}

Siklus II tindakan 1 dilaksanakan pada hari Kamis, tanggal 9 Febuari2017 di kelas V SDN Cijati. Materi pokok dari siklus I tindakan 1 ini, adalah sifat-sifat limas segitiga dengan menggunakan Realistic Mathematic Education dibantu alat peraga berupa model-model limas segitiga baik yang beronggga, pejal maupun kerangka.

\section{3). Refleksi}

Berdasarkan temuan-temuan di atas, maka untuk merencanakan tindakan selanjutnya perlu diperhatikan hal-hal yang ada hubungannya dengan penyajian materi, rencana pembelajaran dan pengkondisian siswa.
Penggunaan Realistic Mathematic Education yang terdiri dari 4 tahap dalam rencana pembelajaran dialokasikan selama 70 menit akan tetapi pada pelaksanaannya berlangsung selama 78 menit, 8 menit lebih lama dari rencana. Hal ini diakibatkan kegiatan diskusi kelompok menghabiskan waktu yang lebih dari rencana. Pada dasarnya, penggunaan Realistic Mathematic Education pada siklus II tindakan 1 dapat ditempuh dengan baik. Akan tetapi pada tahap eksplorasi, yaitu diskusi kelompok belum maksimal karena ada satu orang siswa yang kurang serius dalam memanipulasi model limas segitiga. Sedangkan siswa yang lain setelah diwawancara menyatakan paham mengenai sifat-sifat limas segitiga karena dibantu dengan model limas segitiga dari lidi (kerangka).

Pengkondisian siswa dalam diskusi kelompok, harus lebih diperhatikan. Misalnya meminimalisasi siswa yang kurang serius. Selain itu guru harus selalu tanggap terhadap siswa yang melakukan aktivitas di luar pembelajaran.

\section{Siklus III}

\section{a. Tindakan 1 \\ 1) Perencanaan}

Peneliti berkonsultasi dengan walikelas V untuk menentukan waktu pelaksanaan yang dapat digunakan.

b). Peneliti berkonsultasi dengan walikelas $\mathrm{V}$ materi pokok yang akan digunakan dalam pembelajaran.

c). Peneliti menyusun rencana pelaksanaan pembelajaran yang akan dilaksanakan pada siklus III tindakan II sebagai acuan dalam kegiatan pembelajaran.

d). Peneliti menyusun alat pengumpul data, lembar observasi kegiatan guru dan lembar obervasi kegiatan siswa. Dalam pelaksanaan ini peneliti merencanakan pembelajaran matematika.

e). Menyiapkan media bangun ruang.

f). Menyiapkan kamera untuk dokumentasi selama proses pembelajaran.

g). Mempersiapkan soal tindakan II yang akan dilaksanakan pada untuk mengecek 
seberapa jauh pemahaman siswa tentang materi yang telah diajarkan.

\section{2) Obsevasi}

Berdasarkan data yang diperoleh dari catatan lapangan, lembar observasi lembar wawancara dan hasil pengerjaan LKS baik kelompok maupun individu, maka dapat dianalisis temuan-temuan pada setiap tahap pembelajaran.

Pada waktu siswa mengerjakan LKS sebagai evaluasi akhir, masih ada siswa yang mengalami kekeliruan dalam menjawab LKS mengenai cara menulis nama rusuk, nama diameter, nama jari-jari. Hal ini dapat dilihat dari perolehan nilai siswa dalam LKS individu dan diperoleh dari hasil wawancara lebih lanjut, siswa yang memperoleh nilai di bawah 10 dikarenakan ceroboh dalam menulis nama rusuk, diameter dan jari-jari.

\section{3). Refleksi}

Berdasarkan hasil analisis siklus III tindakan 1, dapat disimpulkan bahwa penggunaan Realistic Mathematic Education yang terdiri dari 4 tahap, secara prosedural dapat ditempuh dengan baik walaupun 5 menit lebih lama dari perencanaan. Kesimpulan tersebut didasarkan atas analisis yang diperoleh bahwa siswa sudah mampu melaksanakan setiap tahap dalam Realistic Mathematic Education dengan baik. Siswa dalam menjawab pertanyaan guru untuk menghubungkan konsep prasyarat, memberikan dugaan terhadap konsep yang akan dipelajari, menemukan sifat-sifat kerucut menggunakan model kerucut, melakukan diskusi kelas melalui laporan hasil diskusi kelompok, menunjukkan dan memberikan contoh kerucut, menarik kesimpulan dan mengerjakan tugas sebagai evaluasi akhir. Adapun tabel hasil penelitian dari muali siklus1, Siklus II dan siklus III dibawah ini.

Tabel 1

Data Hasil Belajar Siswa setiap Siklus

\begin{tabular}{|c|c|c|c|c|c|c|c|c|c|c|}
\hline \multirow{2}{*}{ No } & \multirow{2}{*}{$\begin{array}{l}\text { Nama } \\
\text { Siswa }\end{array}$} & \multicolumn{2}{|c|}{ Siklus I } & \multirow{2}{*}{$\begin{array}{c}\text { Rata-rata } \\
\text { Siklus I }\end{array}$} & \multicolumn{2}{|c|}{ Siklus II } & \multirow{2}{*}{$\begin{array}{c}\text { Rata- } \\
\text { rata Siklus } \\
\text { II }\end{array}$} & \multicolumn{2}{|c|}{ Siklus III } & \multirow{2}{*}{$\begin{array}{l}\text { Rata- } \\
\text { rata Siklus III }\end{array}$} \\
\hline & & $\mathrm{T} 1$ & $\mathrm{~T} 2$ & & $\mathrm{~T} 1$ & $\mathrm{~T} 2$ & & $\mathrm{~T} 1$ & $\mathrm{~T} 2$ & \\
\hline 1 & S1 & 45 & 50 & 47,5 & 50 & 50 & 50 & 60 & 100 & 80 \\
\hline 2 & S2 & 50 & 50 & 50 & 55 & 55 & 55 & 65 & 100 & 82,5 \\
\hline 3 & S3 & 50 & 60 & 55 & 80 & 80 & 80 & 100 & 100 & 100 \\
\hline 4 & S4 & 55 & 60 & 57,5 & 70 & 75 & 72,5 & 80 & 100 & 90 \\
\hline 5 & S5 & 55 & 55 & 55 & 60 & 70 & 65 & 80 & 100 & 90 \\
\hline 6 & S6 & 55 & 55 & 55 & 85 & 85 & 85 & 85 & 100 & 92,5 \\
\hline 7 & S7 & 30 & 30 & 30 & 80 & 80 & 80 & 90 & 100 & 95 \\
\hline 8 & S8 & 40 & 40 & 40 & 70 & 70 & 70 & 70 & 100 & 85 \\
\hline 9 & S9 & 55 & 55 & 55 & 90 & 100 & 95 & 100 & 85 & 92,5 \\
\hline 10 & S10 & 50 & 55 & 5,25 & 85 & 85 & 85 & 85 & 80 & 82, \\
\hline 11 & S11 & 60 & 60 & 60 & 80 & 90 & 85 & 100 & 90 & 95 \\
\hline 12 & S12 & 55 & 60 & 57,5 & 60 & 60 & 60 & 60 & 95 & 77,5 \\
\hline 13 & S13 & 60 & 60 & 60 & 90 & 100 & 85 & 100 & 100 & 100 \\
\hline 14 & S14 & 55 & 55 & 55 & 70 & 70 & 70 & 100 & 100 & 100 \\
\hline 15 & S15 & 60 & 60 & 60 & 70 & 80 & 80 & 100 & 100 & 100 \\
\hline 16 & S16 & 65 & 65 & 65 & 65 & 70 & 67,5 & 100 & 100 & 100 \\
\hline 17 & S17 & 60 & 65 & 62,5 & 70 & 70 & 70 & 95 & 100 & 97,5 \\
\hline 18 & S18 & 60 & 60 & 60 & 80 & 85 & 82,5 & 90 & 100 & 95 \\
\hline 19 & S19 & 60 & 65 & 62,5 & 70 & 80 & 75 & 100 & 100 & \\
\hline \multicolumn{2}{|r|}{ Jumlah } & 1020 & 1060 & 992,75 & 1380 & 1455 & 1412,5 & 1660 & 1850 & 1754,5 \\
\hline & Rata-rata & & & 52,25 & & & 74,34 & & & 92,34 \\
\hline
\end{tabular}

\section{KESIMPULAN}


Kesimpulan yang diperoleh pada penelitian ini hanya berlaku di SDN Cijati Kecamatan Majalengka Kabupaten Majalengka. Berdasarkan hasil-hasil penelitian yang telah diuraikan secara rinci dalam bab IV, maka dapat diambil beberapa kesimpulan sebagai berikut:

1. Pembelajaran volume bangun ruang dengan menggunakan Realistic Mathematic Education, siswa dapat lebih mudah memamhami setiap materi yang dijelaskan dalam KBM khususnya mengenai matematika. Hal ini di tunjukan denga hasil belajar siswa yang meningkat setiap siklusnya. Dimana dalam KBM dengan menggunakan Realistic Mathematic Education siswa dapat lebih kongkret memeragakan apa yang ada dalam materi. Guru disini lebih banyak mengobservasi kegiaatan semua siswa saat proses KBM.

2. Hasil belajar siswa dalam pembelajaran volume bangun ruang mengalami peningkatan setelah dilaksanakan dengan menggunakan Realistic Mathematic Education. Pernyataan tersebut didasarkan atas hasil belajar siswa dengan nilai rata-rata hasil tes individu yang mencapai 92,34. Hal ini menunjukkan bahwa pemahaman siswa cukup merata dengan tingkat pencapaian yang tergolong cukup tinggi pula.

Berdasarkan hasil pengujian hipotesis tindakan, maka dapat disimpulkan bahwa penggunaan Realistic Mathematic Education dan dapat meningkatkan hasil belajar siswa pada pelajaran matematika, khususnya pembelajaran volume bangun ruang di kelas V SD.

\section{B. Saran}

Berdasarkan kajian teoritis dan temuan hasil penelitian yang diperoleh, maka dapat dikemukakan saran berdasarkan kelebihan serta kelemahan Realistic Mathematic Education yang bermanfaat bagi guru, yaitu Pemilihan pendekatan yang akan digunakan dalam proses pembelajaran harus dapat menjadikan siswa lebih interaktif dan memberikan kebebasan kepada siswa dalam mengeluarkan ide - ide yang dimilikinya sehingga proses pembelajaran dapat berjalan secara optimal.

\section{DAFTAR PUSTAKA}

Atmadilaga Didi, ( 2004 ). Buku Pintar Paduan Penulisan Skripsi, Teknis Disentasi, Bandung : P Amir.

Arikunto Suharsumi dkk. ( 2006 ). Penelitian Tindakan Kelas. Jakarta : Bumi Aksara.

Bahri Syaiful dan Zain Aswan, ( 2006 ). Strategi Belajar Mengajar. Jakarta : Rineka Cipta.

Dahar, R . W, ( 1996 ). Teori - teori Belajar, Jakarta : Erlangga.

Depdikbud, ( 1992 ). Pendidikan Matematika I, Jakarta : Depdikbud.

Depdikbud, ( 2003 ). Pendidikan Matematika III, Jakarta : Depdikbud.

Depdikbud, ( 2003 ). Kurikulum 2004 Standar Kompetensi. Jakarta : Depdikbud.

Depdiknas, ( 2005 ). Pedoman Penulisan Karya Ilmiah, UPI : Bandung.

Depdiknas, (2005). Pedoman Penulisan Karya Ilmiah. UPI Bandung

Kusmiati Enung, ( 2003 ). Penggunaan Pendekatan luas daerah pada penjumlahan pecahan kelas IV SD. Skripsi UPI Cibiru Bandung tidak di terbitkan. 
Marni Soetopo, ( 2004 ). Matematika Progresif untuk SD kelas III. Jakarta : Widya Utama.

Rusefendi, ( 2006 ). Pengajaran Matematika untuk Meningkatkan $C B S A$, Bandung : Tarsito.

Rachmat dkk, ( 2004 ). Belajar Matematika untuk SD kelas 3. Bandung : Sarana Panca Karya

Rosmiati Tuti , (2003 ).Upaya meningkatkan hasil pembelajaran pengurangan bilangan cacah melalui alat peraga kartu nilai tempat pada siswa kelas II sekolah dasar.Skripsi UPI kampus Cibiru bandung tidak diterbitkan

Sabandar Jazua, ( 2001 ). Aspek kontektual dalam soal matematika dalam realistik mathematics Education Seminar sehari di gedung Partere Bumi Siliwangi UPI tidak di terbitkan.

Sopian Ujang , (2005 ).Pendekatan matematika realistic dalam pembejaran perkalian bilangan asli untuk kelas II sekolah dasar ; Skripsi UPI kampus cibiru Bandung tidak diterbitkan

Steve Slavin, ( 2004 ). Matematika untuk Sekolah Dasar. Bandung : Pekan Raya.

Suherman Eman dkk, ( 2001 ). Strategi Pembelajaran Matematika
Kompetensi. Bandung : UPI Bandung.

Suharta, ( 2006 ). Matematika Realistik: Apa dan bagaimana ?. [Online]. Tersedia http.//www.Depdiknas.go.id/jurnal/ 38/Matematika \%20 realistik. Htm [ 24 Maret 2007]

TIM PMRI, ( 2003 ). Kumpulan Makalah Lokakarya Pembelajaran Matematika Realistik Bagi Guru $S D$ Laboratorium UPI. Kampus Bumi Siliwangi UPI Bandung.

Turmudi, ( 2001 ). Pendekatan Matematika dalam Pembelajaran Matematika Bandung : Makalah Seminar Sehari di Parteve Bumi Siliwangi UPI Bandung.

Priatna Dudung, ( 2004 )."Pengembangan Lembar Kerja Siswa (LKS) dalam Pembelajaran Pecahan di Kelas IV Sekolah Dasar." Makalah. ( Jurnal ).

Widayana Husen dkk, ( 2006 ). Modul Pendidikan Matematika I : Bandung.

Yuwandi Budi, ( 2005 ). Pintar Matematika untuk SD, Jakarta : Puspa Swara.

Zaenal Aqib, ( 2006 ).Penelitian Tindakan Kelas:Bandung :Yrama Widya 